растворах при различных фиксированных значениях $\mathrm{pH}$. Сделан вывод о том, что сорбент марки «Термоксид» в диапазоне рН от 3,5 до 5,5 обладает одинаковой высокой специфичностью к исследуемым элементам, разделение которых возможно только в слабокислой среде $\mathrm{pH}=1$.

\title{
ABOUT THE POSSIBILITY OF CREATING A HIGH-PERFORMANCE SENSOR BASED ON BORON NITRIDE NANOTUBES
}

\author{
Boroznina N.P. ${ }^{1}$, Zaporotskova I.V. ${ }^{1}$, Boroznin S.V. ${ }^{1}$, Vdovin M.A. ${ }^{1}$ \\ 1) Volgograd State University
}

We have investigated the possibility of boundary modification of boronitride nanotubes with a functional amine group (- $\left.\mathrm{NH}_{2}\right)$ to establish the possibility of creating a highly sensitive sensor exhibiting sorption and sensory activity with respect to alkali metal atoms.

Previous studies have shown that all boron nitride nanotube, regardless of their chirality and conductivity type, belong to semiconductors $[1,2]$, and the possibility of surface modification of the boronitride nanotubes by a carboxyl group $(-\mathrm{COOH})$ at an optimal distance of $1.57 \AA$ [3-5] has been established. Sorption and sensory activity of the resulting complex with respect to alkali metal atoms was also established.

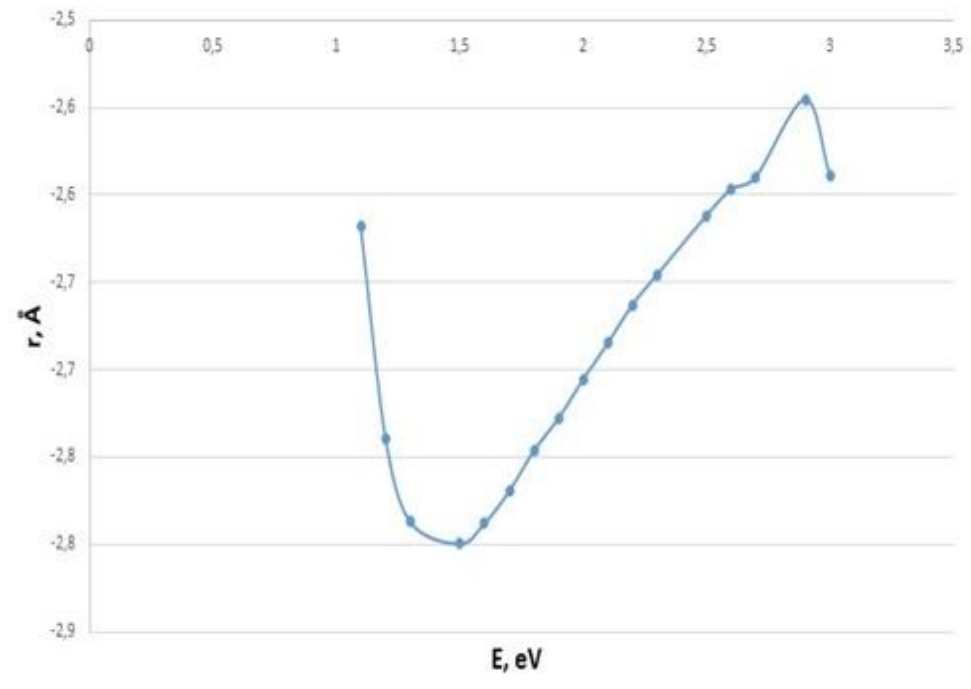

Fig. 1. Surface profile of potential energy of interaction of boron nitride nanotubes and functional amine group.

The study was conducted by a nonempirical calculation method using the Gaussian program. The attachment process was modeled by step-by-step approximation of the nitrogen atom of the amine group along the perpendicular conducted to the edge carbon and nitrogen atoms of the boron nitride nanotube. On the basis of the studies carried out, profiles of potential energy of interaction of boron nitride tube with nitrogen atom of functional group were built, analysis of system geometry found that functional group 
is attached to nanotube at an angle of 178 degrees, interaction distance was $1.5 \AA$, interaction energy was $-2.89 \mathrm{eV}$. Electron density is transferred from amine group nitrogen atom to nanotubes carbon atom.

Thus, analysis of the results led to the creation of a stable "BNT-amine group" complex, which can exhibit sorption and sensory activity with respect to alkali metal atoms.

The reported research was funded by Russian Foundation for Basic Research and the government of Volgograd region, grant № 18-42-343009 r_a, by Russian President's grant №798.2019.1 and by Russian President's grant № MK-1758.2020.8.

1. Zaporotskova I.V. Volgograd: iad VolSU, 438 (2014).

2. Bochkov I.A., Dýachkov E.P., Dýachkov P.N. Journal of Inorganic Chemistry (2014).

3. Polikarpova (Boroznina) N.P., Boroznin S.V., Zaporotskova I.V., Polikarpov D.I., Vil'keeva D. E., Shkodin A.V. IVC-19/ICN+T 2013 and partner conferences. (2013).

4. Polikarpova (Boroznina) N.P., Zaporotskova I.V., Vi'lkeeva D.E., Shkodin A.V., Polikarpov D.I. Materials of XIX International Symposium "Dynamic and Technological Problems of Structural Mechanics and Continuous Media" (2013)

5. Polikarpova (Boroznina) N.P., Zaporotskova I.V., Vi'lkeeva D.E., Shkodin A.V., Polikarpov D.I. Nanoscience \& nanotechnology 2013. 14 ${ }^{\text {th }}$ International Workshop on Nanotechnology. (2013). 